\title{
Perbandingan Pendidikan Karakter Dalam Kurikulum Sekolah Dasar Di Malaysia, India Dan Indonesia
}

\author{
Agustinus Tanggu Daga ${ }^{1}$ \\ ${ }^{1}$ Program studi Pengembangan Kurikulum sekolah Pascasarjana Universitas Pendidikan Indonesia Bandung.
}

\author{
* Agustinus Tanggu Daga: \\ Program studi Pengembangan \\ Kurikulum sekolah \\ Pascasarjana Universitas \\ Pendidikan Indonesia Bandung; \\ Email: agus_daga@yahoo.com
}

\begin{abstract}
Abstrak: Pemerintah berbagai negara telah menjadikan pendidikan karakter sebagai topik pembahasan dan prioritas dalam pengembangan sumberdaya manusia. Pendidikan dasar telah mengimplementasikan pendidikan karakter baik dalam kurikulum maupun praktek pendidikan. Lembaga Pendidikan dasar bertanggung jawab mengembangkan dan melaksanakan pendidikan karakter bangsa dalam rangka memajukan keberadaban bangsa. Pendidikan karakter adalah pendidikan yang didasarkan pada nilai-nilai inti yang berakar dalam kehidupan masyarakat. Melalui pendidikan karakter dihasilkan manusia yang berkualitas dalam seluruh dimensi kepribadiannya. Tujuan penelitian ini adalah mendeskripsikan perbandingan pendidikan karakter dalam kurikulum sekolah dasar tiga negara yaitu Malaysia, India, dan Indonesia. Jenis penelitian ini adalah penelitian kualitatif. Metode yang digunakan adalah deskriptif analisis dokumen. Dan berdasarkan analisis berbagai dokumen kurikulum ditemukan bahwa ketiga negara tersebu mengimpplementasikan pendidikan karakter baik dalam kurikulum maupun dalam kegiatan pendidikan. Ada persamaan dan perbedaan pendidikan karakter ketiga negara tersebut. Kesamaan dan perbedaan tersebut ditinjau dari tiga aspek yaitu pendidikan karakter dalam kurikulum, nilai-nilai karakter dalam kurikulum, dan strategi implementasi pendidikan karakter.

Kata Kunci: Pendidikan Karakter, Pengembangan Kurikulum, SekolahDasar
\end{abstract}

\begin{abstract}
The governments of various countries have made character education a topic of discussion and priority in developing human resources. Basic education has implemented character education both in the curriculum and educational practice. Basic Education Institutions are responsible for developing and implementing national character education in order to advance the nation's civilization. Character education is education based on core values that are rooted in people's lives. Through character education produced quality human beings in all dimensions of his personality. The purpose of this study is to describe the comparison of character education in the elementary school curriculum in three countries, namely Malaysia, India, and Indonesia. This type of research is qualitative research. The method used is descriptive document analysis. And based on analysis of various curriculum documents, it was found that the three countries implement character education both in the curriculum and in educational activities. There are similarities and differences in the character education of the three countries. The similarities and differences are viewed from three aspects, namely character education in the curriculum, character values in
\end{abstract} the curriculum, and the strategy of implementing character education.

\section{Keywords: Character Education, Curriculum Development,} Elementary School. 


\section{Pendahuluan}

Pendidikan karakter telah menjadi isu sentral yang sering dibahas dalam dunia pendidikan. Pemerintah berbagai negara telah menjadikan pendidikan karakter sebagai prioritas karena karakter merupakan salah satu pilar penting dalam kehidupan berbangsa dan bernegara (Hidayati, et.al., 2014: 189). Pendidikan karakter adalah sistem untuk mengembangkan nilai-nilai karakter siswa yang mencakup komponen pengetahuan, kesadaran atau kemauan, dan tindakan yang akan diterapkan ke dalam agama, diri sendiri, masyarakat umum, lingkungan, dan bangsa sebagai manusia yang lengkap (Agung, 2011: 395). Menurut Lickona (dalam Febrianshari, 2018: 89) pendidikan karakter adalah upaya yang dirancang secara sengaja untuk memperbaiki karakter peserta didik. Salah satu tujuan pendidikan karakter adalah mengembangkan kebiasaan dan perilaku peserta didik yang terpuji dan selaras dengan nilai-nilai universal dan tradisi budaya bangsa yang religius.

Istilah karakter berasal dari bahasa Yunani charassein yang berarti to engrave (=mengukir). Membentuk karakter diibaratkan seperti mengukir di atas batu. Karena itu menurut Karen E. Bohlin dkk (dalam Kosim, 2011: 86) pengertian karakter berkembang menjadi tanda khusus atau pola perilaku (an individual's pattern of behavior ... his moral contitution). Sebagai tanda khusus, Agung (2011: 194) memandang bahwa karakter berkaitan dengan cara berpikir dan perilaku individu untuk hidup dan bekerja sama dalam lingkungan keluarga, masyarakat, bangsa dan negara. Seorang individu dengan karakter yang baik adalah individu yang dapat membuat keputusan dan siap untuk bertanggung jawab atas hasil keputusan.

\section{TINJAUAN TEORITIS}

\section{Pendidikan Karakter di Kerajaan Malaysia}

Pendidikan di Malaysia berada dalam penyelanggaraan jawab pemerintah federal. Sistem pendidikan nasional meliputi pendidikan dari prasekolah hingga perguruan tinggi. Pendidikan pratersier (dari pra-sekolah sampai pendidikan menengah) merupakan tanggung jawab
Kementerian Pendidikan Malaysia; sedangkan pendidikan tersier merupakan tanggung jawab Kementerian Pengajian Tinggi Malaysia. Jenis dan jenjang pendidikan di Malaysia dapat dikelompokkan sebagai berikut: pendidikan prasekolah, pendidikan sekolah dasar dan sekolah menengah, pendidikan menengah lanjutan, pendidikan tersier, pendidikan swasta.

Kurikulum Nasional merupakan program pendidikan yang termasuk kurikulum dan kegiatan yang mencakup semua pengetahuan, keterampilan, norma, nilai, unsur kebudayaan dan kepercayaan. Tujuannya adalah untuk membantu perkembangan peserta didik secara utuh dan optimal dari segi jasmani, rohani, mental dan emosi serta menanam dan meningkatkan nilai moral yang diinginkan. Kementerian Pendidikan Malaysia sebagaimana dijelaskan dalam makalah berjudul Analisis Kurikulum Negara Malaysia membagi kurikulum nasional menjadi: kurikulum asuhan dan didikan awal kanak-kanak, kurikulum standard pra-sekolah kebangsaan, kurikulum bersepadu sekolah rendah, kurikulum standard sekolah rendah, kurikulum bersepadu sekolah menengah.

Sejak tahun 1983 pemerintah memutuskan diberlakukan pendidikan moral bagi siswa non muslim yang bersifat wajib dan diujikan pada ujian akhir. Pendidikan moral diberikan kepada siswa non muslim ketika siswa muslim belajar pelajaran agama Islam. Nik Pa (dalam Nik Pa dan Idris, 2008: 293) mengatakan bagi siswa yang beragama islam maka pendidikan nilai dan moral diajar secara langsung melalui mata pelajaran pendidikan agama islam; sementara siswa yang bukan islam maka pendidikan nilai dan moral diajarkan langsung melalui mata pelajaran pendidikan moral. Pada awalnya pendidikan moral hanya diberikan di tingkat Sekolah Dasar. Dalam perkembangannya, pendidikan moral diberlakukan di sekolah menengah dengan diterapkannya Kurikulum Bersepadu Sekolah Menengah.

Menurut Sumintono (2014: 18) sebuah komite yang dibentuk oleh pemerintah telah merumuskan 16 nilai yang kemudian disebut "nilai murni" yang disetujui dan diajarkan kepada siswa. Selanjutnya, 16 nilai tersebut adalah baik hati, kemandirian, hemah tinggi (sopan santun), hormatmenghormati, kasih sayang, keadilan, kebebasan, 
keberanian, kesehatan fisik dan dan mental, kejujuran, kerajinan, kerjasama, kesederhanaan, bersyukur, rasional, dan semangat gotong royong. Nilai-nilai murni tersebut diturunkan dari nilai-nilai agama, tradisi, kebiasaan masyarakat, serta mempertimbangankan aspek universal. Semua nilai tersebut berhubungan erat dengan kehidupan sehari-hari, hubungan antara manusia dalam keluarga, teman sejawat, masyarakat ataupun organisasi.

Menurut Rahman dan Chang (dalam Sultoni, 2016: 179) pendidikan moral di Malaysia dilakukan melalui metode interaksi sosial di sekolah dan di luar sekolah. Interaksi disekolah dilaksanakan dalam proses pembelajaran di kelas. Pendidikan moral dimplementasikan dengan metode pembelajaran langsung (direct learning). Selain melalui mata pelajaran, pendidikan moral dilakukan oleh guru mata pelajaran melalui integrasi nilai-nilai ke dalam setiap matapelajaran. Kebijakan terakhir ini menyebabkan guru-guru merasa terbebani karena saat mengajar ia juga dituntut menjadi role model bagi siswa dalam proses pembelajaran. Pendidikan moral luar sekolah bermaksud memberikan situasi yang membantu pelajar untuk menerapkan nilai nilai moral dalam kehidupan sahari-hari. Menurut Sumintono (2014: 19) metode lain yang digunakan guru adalah metode menghafal; dimana siswa diminta untuk menghafalkan materi pendidikan moral. Hal ini terjadi karena guru-guru tidak memiliki kapasitas dan keterampilan dalam melakukan pendidikan moral di kelas.

\section{Pendidikan Karakter di Republik Demokrasi India}

Kementerian Pengembangan Sumber Daya Manusia bertanggung jawab atas pendidikan di semua tingkatan. Kementarian ini terdiri dari dua departemen yaitu Departemen Pendidikan dan Literasi Sekolah dan Departemen Pendidikan Tinggi. Departemen Pendidikan dan Literasi Sekolah bertanggung jawab untuk pendidikan dasar, pendidikan menengah, dan pendidikan orang dewasa dan melek huruf. Departemen Pendidikan Tinggi bertanggungjawab untuk universitas dan pendidikan tinggi, pendidikan teknis, dan pendidikan minoritas. Sistem pendidikan India pada awalnya didasarkan pada model Inggris, tetapi berubah dari tahun ke tahun menjadi sistem $10+2$ +3 , yaitu 10 tahun pendidikan dasar, 2 tahun pendidikan menengah umum dan 3 tahun pendidikan tinggi. Dasar untuk struktur semua bagian dari sistem pendidikan adalah Kebijakan Nasional tentang Pendidikan.

Tahun sekolah untuk sekolah dasar dan menengah adalah dari Juli hingga April. Sedangkan untuk universitas, tahun akademik berjalan dari Juni atau Juli hingga akhir Maret atau April. Lembaga pendidikan di daerah dengan ketinggian lebih tinggi (sekitar $2 \%$ dari total) mengikuti jadwal yang berbeda, mulai bulan Maret dan biasanya berjalan hingga Desember. Sebagian besar universitas membagi tahun akademik menjadi trimester, sementara beberapa bekerja dengan sebuah sistem semester. Tidak ada sistem khusus sekolah musim panas. Jenjang pendidikan meliputi Pendidikan Dasar dan Menengah (Primary and Secondary Education), Pendidikan Kejuruan Menengah Atas (Senior Secondary Vocational Education), Persiapan Masuk Pendidikan Tinggi (Admission to Higher Education), Pendidikan Tinggi (Higher Education), dan Pendidikan Universitas (University Education).

Sistem pendidikan India tersusun atas: a) Pra-sekolah: Pendidikan pada level ini tidak wajib. Sistem Montessori sangat populer di tingkat prasekolah. b) Sekolah bermain swasta: melayani pendidikan anak usia 18 bulan dan tiga tahun. c) Taman kanak-kanak: Terdiri dari taman kanakkanak bawah (anak usia 3-4 tahun) dan taman kanak-kanak atas (anak usia 4-5). d) Sekolah dasar: Standar/kelas/kelas 1- 5 (anak usia 6-10). e) Sekolah menengah/sekolah menengah atas: Standar/kelas/kelas 6-8 (anak usia 11-14 tahun). f) Sekolah menengah: Standar/kelas/kelas 9 dan 10 (anak usia $14-16$ tahun). g) Tinggi menengah atau pra-universitas: standar / kelas / kelas 11 dan 12 (untuk usia 16 hingga 18 tahun).

Pendidikan sekolah di India telah mengembangkan nilai-nilai dasar dan masyarakat yang berlandaskan pengetahuan agama dan semangat yang benar. Hal ini menjadi dorongan bahwa kurikulum sekolah India memasukkan penanaman nilai-nilai dasar dan kesadaran semua agama besar negara sebagai salah satu komponen utama. Nilai pendidikan dan pendidikan tentang agama tidak membentuk subyek studi atau ujian yang terpisah, melainkan terintegrasi secara bijaksana dengan semua mata pelajaran di bidang skolastik serta semua kegiatan dan program di bidang skolastik sehingga tujuan pendidikan nilaidan agama akan secara langsung dan tidak 
langsung tercapai di ruang kelas, di tempat-tempat pertemuan sekolah, taman bermain, pusat budaya dan tempat-tempat lain yang relevan.

Nilai-nilai yang diabadikan dalam Konstitusi India mengarah pada prinsip-prinsip kesetaraan dan keadilan sosial, penghargaan terhadap nilai-nilai budaya, dan martabat semua manusia. Nilai-nilai seperti kesetaraan, persaudaraan dan keadilan dapat mendorong inklusivitas dalam masyarakat tanpa membedakan warna, budaya, latar belakang ekonomi atau sosial, kasta, agama, jenis kelamin atau komunitas mereka.. Kerangka Kurikulum Nasional (National Curriculum Framework) sangat menganjurkan nilai-nilai seperti kerja sama, penghormatan terhadap hak asasi manusia, toleransi, keadilan, kewarganegaraan yang bertanggung jawab, keanekaragaman, penghormatan terhadap demokrasi dan resolusi konflik damai (Patra and Mete, 2015: 2).

Pendidikan merupakan proses menanamkan nilai-nilai untuk melengkapi siswa dalam menjalani kehidupan; yakni kehidupan yang memuaskan individu sesuai dengan nilai-nilai dan cita-cita yang diharapkan oleh masyarakat. Karena itu pendidikan karakter dapat diberikan melalui beberapa cara, yaitu: 1) Individu (The individual): Individu merupakan bangunan pertama dari arsitektur nilai. Agar integrasi nilai terjadi maka kebutuhan anak akan keamanan, martabat, identitas, dan kesejahteraan harus dipenuhi. Kebutuhan fisik, emosional, sosial dan spiritual anak harus dipenuhi untuk memastikan perkembangan yang harmonis dari semua aspek kepribadiannya. 2) Keluarga (The family): Keluarga yang memainkan peran penting dalam pendidikan nilai-nilai pada anak. Anak yang tumbuh di rumah yang sarat konflik tidak mungkin berorientasi pada perdamaian. Hubungan yang sehat dalam keluarga menciptakan nilai-nilai yang sehat. Rumah adalah ruangr anak untuk menanamkan nilai-nilai. 3) Komunitas (The community): Hubungan antara individu dan komunitas yang baik memainkan peran penting dalam pembentukan identitas individu, dan menentukan tingkat keamanan diri anak. Nilai-nilai pendidikan sangat membantu meminimalisir rasa tidak aman masyarakat dan meningkatkan rasa memiliki. 4) Masyarakat (The society): Masyarakat adalah keluarga besar yang ditandai oleh keragaman individu, dan kepentingan keluarga dan komunitas. Ada hubungan timbal balik antara individu dan masyarakat yang menjadi bagiannya. Tradisi / adat / tradisi sosial diinternalisasi selama proses pertumbuhan dalam masyarakat. Individu, keluarga dan komunitas yang terdiri dari masyarakat memiliki tugas untuk menghindari pengejaran, advokasi, metode dan tujuan yang merusak nilai-nilai. 5) Negara (The nation): Negara merupakan bagunan nilai tertinggi. Negara yang membiarkan warganya dikalahkan oleh kebencian dan negativitas membiarkan energinya terbuang sia-sia. Nilai-nilai adalah dasar untuk kemajuan dan kesejahteraan. Bangsa-bangsa yang damai terdiri dari bangunan nilai-nilai global (Patra and Mete, 2015: 3-5).

\section{Pendidikan Karakter di Republik Indonesia}

Dalam Undang-Undang Nomor 20 tahun 2003 bab II pasal (3)dinyatakan bahwa pendidikan bertujuan untuk berkembangnya potensi peserta didik agar menjadi manusia yang beriman dan bertakwa kepada Tuhan Yang Maha Esa, berakhlak mulia, sehat, berilmu, cakap, kreatif, mandiri, dan menjadi warga negara yang demokratis serta bertanggung jawab. Penyelenggaraan pendidikan di Indonesia berada dalam tanggungjawab Kementerian dan Kebudayaan untuk pendidikan dasar dan menengah serta Kementerian Riset Teknologi dan Pendidikan Tinggi untuk pendidikan tinggi. Dalam perjalanan waktu, Kementerian Pendidikan dan Kebudayaan bertanggungjawab terhadap seluruh penyelenggaraan pendidikan; mulai dari pendidikan dasar hingga pendidikan tinggi.

Kurikulum pendidikan di Indonesia memiliki sejarah panjang dari tahun ke tahun. dalam perjalanan pengembangankurikulum terjadi beberapa perubahan kurikulum. Menurut Kaimuddi (2014: 58) kurikulum 2013 berorientasi pada pengembangan pendidikan karakter peserta didik. Hal ini ditunjukkan dengan adanya integrasi baik secara vertikal dan horinsontal antar mata pelajaran dan jenjang pendidikan, integrasi antara ranah kognitif, afektif, dan psikomotorik. Keterpaduan mata pelajaran dan ranah capaian tujuan pembelajaran secara detil tercermin dalam pengorganisasian kompetensi inti berbasis kelas yang meliputi KI-1 sampai KI-4.

Landasan yuridis pendidikan karakter di Indonesia adalah Permendikbud Nomor 20 tahun 2018 tentang penguatan pendidikan karakter pada satuan pendidikan formal. Dalam pasal 1 ayat (1) dinyatakan bahwa penguatan pendidikan karakter 
adalah gerakan pendidikan di bawah tanggung jawab satuan pendidikan untuk memperkuat karakter peserta didik melalui harmonisasi olah hati, olah rasa, olah pikir, dan olah raga dengan pelibatan dan kerja sama antara satuan pendidikan, keluarga, dan masyarakat sebagai bagian dari gerakan nasional revolusi mental.

Kementerian Pendidikan Nasional (dalam Hartono, 2014: 262-263) telah merumuskan 18 nilai Karakter yang bersumber dari agama, Pancasila, budaya, dan tujuan pendidikan nasional yang akan ditanamkan dalam diri peserta didik sebagai upaya membangun karakter bangsa. 18 nilai karakter itu meliputi: religius, jujur, toleransi, disiplin, kerja keras, kreatif, mandiri, demokrasi, rasa ingin tahu, kebangsaan, cinta tanah air, menghargai prestasi, bersahabat/komunikatif, cinta damai, gemar membaca, peduli lingkungan, peduli sosial, tanggungjawab.

Dalam pasal 2 Permendikbud nomor 20 tahun 2018 dinyatakan dengan jelas bahwa pendidikan karakter dilaksanakan dengan menerapkan nilai-nilai Pancasila dalam pendidikan karakter terutama nilai-nilai religius, jujur, toleran, disiplin, bekerja keras, kreatif, mandiri, demokratis, rasa ingin tahu, semangat kebangsaan, cinta tanah air, menghargai prestasi, komunikatif, cinta damai, gemar membaca, peduli lingkungan, peduli sosial, dan bertanggung jawab. Nilai-nilai tersebut merupakan perwujudan dari lima nilai utama yang saling berkaitan yaitu religiusitas, nasionalisme, kemandirian, gotong royong, dan integritas yang terintegrasi dalam kurikulum.

Permendikbud Nomor 20 tahun 2018 berbicara tentang pendekatan dan metode pelaksanaan penguatan pendidikan karakter di sekolah. Pada pasal 5 ayat (3) dinyatakan bahwa optimalisasi pelaksanaan penguatan pendidikan karakter pada TK dilaksanakan melalui kegiatan intrakurikuler; sedangkan pada jenjang pendidikan dasar dan menengah dilaksanakan melalui kegiatan intrakurikulur, kokurikuler, dan ekstrakurikuler yang dilaksanakan secara kreatif dan terpadu. Sedangkan pada pasal 6 dinyatakan bahwa pelaksanaan pelaksanaan penguatan pendidikan dengan mengoptimalkan fungsi tiga mitra pendidikan dilaksanakan dengan pendekatan berbasis kelas, budaya sekolah, dan masyarakat

\section{Metode Penelitian}

Jenis penelitian ini adalah penelitian kualitatif. Penelitian kualitatif adalah suatu proses penelitian dan pemahaman yang berdasarkan pada metodologi yang menyelidiki suatu fenomena sosial dan masalah manusia (Iskandar, 2009: 11). Metode penelitian yang digunakan adalah metode deskriptif analitis. Deskriptif berarti memaparkan sesuatu dengan kata-kata yang jelas dan terperinci. Analitis berarti penyelidikan terhadap sesuatu untuk mengetahui keadaan yang sebenarnya. Menurut Peter Connolly (dalam Aulia, 2018: 14) deskriptif analisis berarti sebuah cara atau teknik penelitian dengan menggambarkan suatu pengetahuan dengan penulisan ataupun ucapan dan kemudian membaginya ke dalam beberapa bagian untuk lebih lanjut diadakan penyelidikan kritis dan pengujian untuk mendapatkan hasil yang benar. Dalam konteks penelitian ini metode ini digunakan untuk mendeskripsikan penndidikan karakter dalam kurikulum 3 negara yaitu Malaysia, India, dan Indonesia. Untuk mendeskripsikan pendidikan karakter tersebut peneliti mengkaji dokumenkurikulum dan dokumen-dookumen lain yang berkaitan dengan kurikulum ketiga negara tersebut.

\section{Hasil Dan Pembahasan}

\section{Pendidikan Karakter dalam Kurikulum}

Dapat dikatakan bahwa ketiga negara telah menempatkan pendidikan karakter dalam kurikulum pendidikan yang diimplementasikan pada berbagai jenis dan jenjang pendidikan. Di negara Malaysia, pendidikan karakter diberikan dalam bentuk pendidikan moral dan pendidikan agama. Pendidikan moral diberikan kepada siswa non muslim ketika siswa muslim belajar pelajaran agama Islam. Melalui penerapan Kurikulum Bersepadu Sekolah Menengahmaka pendidikan moral dilaksanakan di sekolah dasar hingga sekolah menengah.

Di negara India, pendidikan karakter dilaksanakan dengan berlandaskan pada pengetahuan agama dan semangat yang benar untuk mengembangkan nilai-nilai dasar dan masyarakat di India. Karena itu integrasi pendidikan nilai-nilai dasar dan agama sebagai salah satu komponen utama dalam pendidikan di India. Namun, pendidikan nilai dan pendidikan tentang agama tidak didesain sebagai satu mata pelajaran tetapi 
terintegrasi dengan mata pelajaran dan berbagai kegiatan pendidikan di sekolah.

Selanjutnya di Indonesia, pendidikan karakter menjadi gerakan pendidikan di yang diselenggarakan oleh sekolah (satuan pendidikan) dengan tujuan memperkuat karakter siswa. Pelaksanaan pendidikan karakter melalui harmonisasi olah hati, olah rasa, olah pikir, dan olah raga yang melibatkan sekolah, keluarga dan masyarakat menjadi bagian integrase dari gerakan nasional revolusi mental. Kurikulum 2013 yang sedang berlaku saat ini di Indonesia berorientasi pada pendidikan karakter. Dalam kurikulum 2013 ada integrasi secara vertikal dan horisontal antar mata pelajaran dan jenjang pendidikan, integrasi antara domain kognitif, afektif, dan psikomotorik. Keterpaduan mata pelajaran dan ranah capaian tujuan pembelajaran tercermin dalam desain kompetensi inti yang meliputi KI-1 sampai KI-4.

\section{Nilai-Nilai Karakter dalam Kurikulum}

Malaysia telah menerapkan 16 nilai dalam pendidikan karakter. Nilai-nilai tersebut sebagai nilai murni. 16 nilai tersebut meliputi: baik hati, kemandirian, hemah tinggi (sopan santun), hormatmenghormati, kasih sayang, keadilan, kebebasan, keberanian, kesehatan fisik dan dan mental, kejujuran, kerajinan, kerjasama, kesederhanaan, bersyukur, rasional, dan semangat gotong royong. Nilai-nilai murni tersebut diturunkan dari nilai-nilai agama, tradisi, kebiasaan masyarakat. dalam perkembangan 16 nilai tersebut direvisi menjadi 7 nilai yaitu nilai berkaitan dengan perkembangan diri, nilai berkaitan dengan kekeluargaan, nilai berkaitan dengan alam sekitar, nilai berkaitan dengan patriotisme, nilai berkaitan dengan hak asasi manusia, nilai berkaitan dengan demokrasi, dan nilai berkaitan dengan keamanan dan keharmonian.

Di India, nilai-nilai dalam kurikulum mengarah pada prinsip-prinsip kesetaraan dan keadilan sosial, penghargaan terhadap nilai-nilai budaya, dan martabat semua manusia. Kerangka Kurikulum Nasional (National Curriculum Framework) sangat menganjurkan nilai-nilai seperti kerja sama, penghormatan terhadap hak asasi manusia, toleransi, keadilan, kewarganegaraan yang bertanggung jawab, keanekaragaman, penghormatan terhadap demokrasi dan resolusi konflik damai.
Di Indonesia, nilai-nilai dalam kurikulum telah dirumuskan oleh Kementerian Pendidikan Nasional tahun 2014, yaitu religius, jujur, toleransi, disiplin, kerja keras, kreatif, mandiri, demokrasi, rasa ingin tahu, kebangsaan, cinta tanah air, menghargai prestasi, bersahabat/komunikatif, cinta damai, gemar membaca, peduli lingkungan, peduli sosial, tanggungjawab. Kemudian dalam Permendikbud nomor 20 tahun 2018 dinyatakan pendidikan karakter berkandaskan pada nilai-nilai Pancasila. Nilai-nilai itu adalah religius, jujur, toleran, disiplin, bekerja keras, kreatif, mandiri, demokratis, rasa ingin tahu, semangat kebangsaan, cinta tanah air, menghargai prestasi, komunikatif, cinta damai, gemar membaca, peduli lingkungan, peduli sosial, dan bertanggung jawab. Nilai-nilai tersebut terintegrasi dalam kurikulum pendidikan.

\section{Strategi Implementasi Pendidikan Karakter dalam Kurikulum}

Pendidikan nilai di Malaysia dilakukan melalui metode interaksi sosial di sekolah dan di luar sekolah. Interaksi disekolah dilaksanakan dalam proses pembelajaran langsung, baik oleh guru pendidikan moral maupun oleh guru kelas. Pendidikan moral di luar sekolah dilaksanakan dengan penciptaan situasi-situsi konkrit untuk menerapkan nilai-nilai moral.

Di India, Pendidikan nilai terkandung dengan jelas dalam berbagai buku pelajaran di sekolah. Perencanaan dan implementasi pendidikan karakter inisiatif dan inspirasi guru dalam menemukan sumber belajar. Pendidikan karakter dapat diberikan melalui beberapa cara, yaitu: individu (the individual), keluarga (the family), komunitas (the community), masyarakat (the society), negara (the nation).

Di Indonesia, pelaksanaan pelaksanaan pendidikan karakter dengan mengoptimalkan fungsi mitra pendidikan dilaksanakan dengan pendekatan berbasis kelas, budaya sekolah, dan masyarakat. Pendidikan karakter berbasis kelas dilaksanakan dengan mengintegrasikan nilai-nilai dalam dokumen kuriulum (RPP), dalam proses dan penilaian pembelajaran. Pendidikan karakter melalui budaya sekolah dilaksanakan dengan pembeiasaan, keteladanan, peraturan atau norma sekolah. pendidikan karakter berbasis dilaksanakan dengan melibatkan komite sekolah, potensi dan berbagai program lingkungan masyarakat. Selanjutnya, pendidikan karakter pada taman 
kanak-kanak dilaksanakan melalui kegiatan intrakurikuler. Sedangkan pada jenjang pendidikan dasar dan menengah dilaksanakan melalui kegiatan intrakurikulur, kokurikuler, dan ekstrakurikuler yang dilaksanakan secara kreatif dan terpadu.

\section{Perbandingan Pendidikan Karakter dalam Kurikulum Sekolah Dasar}

1. Persamaannya

a. Pendidikan karakter pada ketiga negara tersebut telah menjadi bagian integral dari kurikulum pendidikan di sekolah. Kurikulum ketiga negara tersebut telah menempatkan pendidikan karakter dalam peencanaan, pelaksanaan dan penilaian pendidikan.

b. Pendidikan karakter pada ketiga negara tersebut didasarkan pada nilai-nilai yang mendasari kehidupan negara tersebut. Negara Malaysia mendasarkan pendidikan karakter pada pendidikan moral dan agama. Negara India mendasarkan pendidikan karakter pada nilai-nilai murni. Negara Indonesia mendasarkan pendidikan karakter pada nilai-nilai Pancasila.

c. Strategi atau metode pendidikan karakter (pendidikan nillai) pada ketiga negara melibatkan sekolah, keluarga dan masyarakat serta negara. Pendidikan karakter lebih didesain terintegrasi dengan mata pelajaran di sekolah.

2. Perbedaannya

a. Pendidikan karakter di negara Malaysia: pendidikan karakter diberikan dalam bentuk pendidikan moral dan pendidikan agama. Artinya, nilai-nilai moral dan agama menjadi tekanan dan prioritas pendidikan karakter di Malaysia. Hal ini dapat dimaklumi bahwa agama islam menjadi agama negara Malaysia. Selain itu, dengan penerapan Kurikulum Bersepadu Sekolah Menengah maka pelaksanaan pendidikan karakter diprioritaskan pada pendidikan dasar dan menengah.

b. Pendidikan karakter di negara India: Pendidikan karakter selain didasarkan pada nilai moral dan agama juga didasarkan pada nilai-nillai spiritual yang hidup dalam masyarakat India. Dan nilai-nilai spiritual tersebut dimasukan dalam dokumen kurikulum pendidikan. Implementasi pendidikan karakter terjadi secara lebih meluas dengan melibatkan siswa (individu), keluarga (family), komunitas (community), masyarakat (society), negara (nation).

c. Pendidikan Karakter di negara Indonesia: pendidikan karakter diatur oleh pemerintah melalui Kementarian Pendidikan. Pendidikan karakter di Indonesia melibatkan 3 pihak yaitu sekolah, keluarga, dan masyarakat. Pendidikan karekter tidak berlandaskan pada agama tetapi pada ideology bangsa yaitu Pancasila. Namun, nilai-nilai agama terkandung dalam pendidikan karakter. Setiap sekolahmengembangkan pendidikan karakter baik dalam dokumen kurikulum maupun dalam implementasi dan penilaian sesuai dengan nilai-nilai inti (core values) yang mendasari filsafat pendidikan sekolah tersebut. Kurikulum 2013 sebagai kelanjutan dari kurikulum sebelumnya bertujuan untuk mempersiapkan manusia Indonesia agar memiliki kemampuan hidup sebagai pribadi dan warga Negara yang beriman, produktif, kreatif, inovatif, dan afektif serta mampu berkontribusi pada kehidupan masyarakat, berbangsa, bernegara, dan peradaban dunia.

\section{Kesimpulan}

Pendidikan memberikan pengaruh besar terhadap peningkatan kualitas dan perilaku hidup masyarakat karena pendidikan merupakan media transformasi kepribadian dan pengembangan diri seseorang. Pelaksanaan pendidikan karakter di lingkungan pendidikan formal khususnya padapendidikan dasar memiliki pengaruh yang efektif dalam membentuk karakter siswa sekolah dasar dalam rangka mengembangkan karakter bangsa.

Perbandingan pendidikan karakter dalam kurikulum pendidikan dasar ketiga negara: Malaysia, India, dan Indonesia menunjukan bahwa pendidikan karakter telah menjadi salah satu komponen penting dalam pengembangan kurikulum baik sebagai dokumen maupun dalam implementasi secara nyata di kelas. Ketiga negara tersebut dari aspek nilai-nilai karakter maupun strategi implementasi pendidikan karakter memiliki 
kesamaan dan perbedaan. Namun yang terpenting adalah bahwa ketiga negara tersebut tidak saja menyadari pentingnya pendidikan karakter bagi generasi muda tetapi telah mengimplementasikan dalam program dan peleksanaan pendidikan pada masing-masing negara.

\section{Daftar Pustaka}

Agung, Leo. (2011). Character Education Integration In Social Studies Learning. International Journal of History Education. 12 (2), p. 392- 403.

Aulia, Heni. (2018). Spiritualitas Kaum Biarawati: Studi Analisis Biara Susteran Jesus Maria Joseph Ciputata Tangerang Selatan. (Skripsi). Jakarta: Jurusan Studi AgamaAgama Fakultas Ushuluddin Universitas Negeri Syarif Hidayatullah.

Febrianshari, Deddy. (2018). Analisis Nilai-Nilai Pendidikan Karakter Dalam Pembuatan Dompet Punch Zaman Now. Jurnal Pemikiran dan Pengembangan SD. 6 (1), hlm. 88-95.

Hartono. (2014). Pendidikan Karakter Dalam Kurikulum 2013 Character Education In Curriculum 2013. Jnana Budaya. 19 (2), hlm. 259-268.

Hidayati, Abna, et.al. (2014). The Development of Character Education Curriculum For Elementary Student In West Sumatera. International Journal of Education and Research. 2 (6), p. 189-198.

Iskandar. (2009). Metodologi Penelitian Kualitatif. Jakarta: Gaung Persada Press.

Kaimuddin. (2014). Implementasi Pendidikan Karakter Dalam Kurikulum 2013. Dinamika Ilmu. 14 (1), hlm. 47-63.

Kosim, Mohammad. (2011). Urgensi Pendidikan Karakter. Karsa. 11 (1), hlm. 85-92.

Nik Pa, Nik Aziz dan Idris, Noraini. (2008). Perjuangan Memperkasakan Pendidikan di Malaysia: Pengalaman 50 Tahun Merdeka. Kuala Lumpur: Utusan Publication \& Distributors Sdn Bhd.

Nuffic. (2015). Education System India Described and Compared with the Dutch System. 2nd Edition. New Delhi: Nuffic.

Patra, J . N and Mete, J. (2015). Value Education System in India. (Makalah).Kalyani:
Department of Education, University of Kalyani.

Permendikbud Nomor 20 Tahun 2018 tentang Penguatan Pendidikan Karakter Pada Satuan Pendidikan Formal.

Sumintono, Bambang. (2012). Pendidikan Moral di Malaysia: Tantangan dan Implementasi Pendidikan Karakter di Sekolah. Jurnal Pendidikan Karakter. 2 (1), hlm. 14-22.

Sultoni, Achmad. (2016). Pendidikan Karakter dan Kemajuan Negara: Studi Perbandingan Lintas Negara. Journal of Islamic Education Studies. 1 (1), p. 184-207.

Undang-Undang Nomor 20 Tahun 2003 Tentang Sistem Pendidikan Nasional. 